\title{
Control of intestinal helminths in schoolchildren in Low-Napo, Ecuador: impact of a two-year chemotherapy program
}

\author{
Controle de helmintos intestinais em crianças com idade escolar em Baixo-Napo,
} Equador: impacto de um programa de tratamento de dois anos de duração

Miguel San Sebastián ${ }^{1}$ and Santiago Santi ${ }^{2}$

\begin{abstract}
A school-based control program of intestinal helminths was undertaken among schoolchildren in the Low-Napo region, north-eastern Ecuador. Forty-eight percent of children were infected with one or more helminths at the first examination. The prevalence at the baseline was Ascaris $33.2 \%$ followed by hookworm $24.1 \%$ and Trichuris $6.5 \%$. Sex was found to be a significant factor influencing the prevalence of hookworm and Trichuris. Prevalence was compared 9 months and 18 months after treatment. After 9 months. Ascaris and Trichuris prevalence had decreased but not hookworm. All of them increased after 18 months. The findings suggest that only a course of mebendazol had a minor effect on the control of helminth infections.
\end{abstract}

Key-words: Intestinal helminths. Control. Schoolchildren. Ecuador.

Resumo Um programa de controle da helmintíase foi realizado entre escolares de região do Baixo-Napo, nordeste do Equador. À primeira verificação, foi constatado que quarenta e oito por cento das crianças estavam infestadas por um ou mais helmintos. As prevalências das helmintíases apresentaram a seguinte distribuição: Ascaris, 32,2\%; ancilostomies, 24,1\% e Trichuris, $6,5 \%$. A variável sexo foi considerada um importante fator ligado as prevalências do ancilostomies e do Trichuris. As prevalências foram comparadas, após 9 e 18 meses. Após 9 meses, apresentaram-se diminuídas, tanto a prevalência da ascaridíase, quanto a da tricocefalíase. Entretanto, após 18 meses, a prevalência das três helmintíases apresentaram-se elevadas. Os achados sugerem que apenas um tratamento con mebendazol produz um pequeno impacto no controle da infecção por helmintos.

Palavras-chaves: Helmintos intestinais. Controle. Escolares. Equador.

Intestinal worm infections have been shown to contribute to malnutrition ${ }^{7}$ and to an apparent effect on cognitive development in children ${ }^{5}$. Although attainment of adequate and culturally acceptable environmental sanitation and personal hygiene is the ultimate solution to the problem, provision of periodic mass chemotherapy is justifiable to control the infection and its complications in the short term ${ }^{10}$. The availability of safe, effective antihelminthic drugs ensures that community-based chemotherapy is the principal means to achieve these short-term objectives ${ }^{6}$. In community-based studies, chemotherapy targeted at children has been found to be effective in reducing intensity not only in the treated children but also in untreated adults ${ }^{3}$.

\footnotetext{
1. Instituto de Epidemiologla y Salud Comunitaria Manuel Amunarriz, Coca, Orellana, Ecuador; 2. Asociacion de Promotores de Salud Sandi Yura, Coca, Orellana, Ecuador.

This study formed part of the Aguarico primary health care program supported by Medicus Mundi Andalucía, Spain.

Address to: Dr. Miguel San Sebastián. Instituto de Epidemiologla y Salud Comunitaria Manuel Amunarriz. Apdo. 17-21-01918, Quito, Ecuador.

Tel.: (02) 257689; Fax: (02) 449763

E-mail:admin@mmcoca.ecuanex.net.ec

Recebido para publicação em 19/10/98.
} 
Information from hospital records has indicated that soil-transmitted helminths are a common infection among indigenous populations in the Amazon basin of Ecuador ${ }^{2}$. However, information on the prevalence of these infections is lacking in rural communities of this area.
This paper presents the outcome of a 2-year school chemotherapy-based program for the control of intestinal helminth infections among schoolchildren of the Naporuna ethnicity in LowNapo area, Ecuador. Aspects of the community involvement in the implementation of the program are also described.

\section{MATERIAL AND METHODS}

Study area and organization of the program. The Naporuna people are an Amazonian indigenous ethnicity who live scattered along the $300 \mathrm{~km}$ of Napo river and its tributaries (north-eastern Ecuador). They number approximately 15,000, making their living by hunting, fishing and subsistence agriculture.

Homes are of a simple construction, with a raised floor, bamboo walls and a thatched roof made of palm leaves. They lack basic amenities such as electricity, piped water supply and adequate facilities for refuse and sewage disposal. Water is collected from the rain or streams near home. The river is for most communities the only way of communication.

The whole Naporuna territory (about $15,000 \mathrm{~km}^{2}$ ) is divided in 55 communities, which are organized into a Federation of Communities (Federación de Comunas Unión de Nativos de la Amazonía Ecuatoriana, FCUNAE). In 1991, FCUNAE started a primary health care (PHC) program in 25 communities with training of 50 community health workers (CHWs). CHWs are organized in the Sandi Yura Community Health Workers Association, legalized by the Health Ministry of Ecuador.

One of the objectives of the PHC program was to collect data on the health status of schoolchildren. The control of intestinal helminths program was developed as result of this initiative.

The objectives of the control program were a) to determine the prevalence of intestinal helminth infections in schoolchildren; b) to reduce the prevalence of helminth infections within 2 years; and c) to develop a school-based control program through the network of the $\mathrm{CHWs}$ association.

During a five day seminar, Sandi Yura coordinators explained the objectives of the program, procedures and tasks to the CHWs.

Prior to the initiation of the program in schools, communities were visited and the program explained by the CHWs. It was stressed that teachers together with $\mathrm{CHWs}$ were to play a crucial role in the implementation. Consent of the parents was obtained. After each examination, communities were informed by $\mathrm{CHW}$ s regarding the outcome and treatment that schoolchildren received.

Study design and methods. Baseline data on intestinal helminths was collected during October 1991 from all 25 schools (total 864 children) situated between Coca and Nuevo Rocafuerte villages in Napo province. Results of this study have been presented elsewhere ${ }^{9}$. Due to logistic and financial limitations, for evaluation of the program 216 children ( $25 \%$ of the total sample), aged 6 to 13 years (mean $=8.6 ; S D=2.1$ ), were randomly selected and followed-up during 18 months.

Labeled plastic containers were distributed to schoolchildren by $\mathrm{CHW}$ s with instructions to bring a stool sample. On the same day, stools were collected and specimens examined in the field a few hours later by direct examination of the fresh stool samples. Preparations were scanned by one of the technically trained $\mathrm{CHWs}$ and $25 \%$ of these were re-examined at random by a doctor for quality control. The day following the examination, teachers were given a list of the infected children, dosage required and ways of dispensing it. This activity was supervised by the communities' CHWs.

Targeted chemotherapy to the infected children with mebendazol (Mebendazol MK, McKenson) 100mg twice a day per three days was given. To evaluate the impact, a single stool sample from all the schoolchildren was examined 9 (June 1992) and 18 months later (March 1993).

Data analysis. Data was analyzed with the EPI-INFO 6 statistical program. Chi-squared tests (Yates corrected and Fisher's exact test with twotailed analysis when the sample was small) were performed to test whether associations between variables were statistically significant. 


\section{RESULTS}

In October 1991, baseline stool samples were collected from 216 (47.7\% females) schoolchildren. All but 17 (7.8\%) returned with samples all three times. Data presented are from these 199 children. No adverse reaction to the drugs were reported.

In 1991, intestinal helminth infections were highly prevalent with nearly half (48.2\%) of children infected with one or more helminths at the first examination (Table 1). The main prevalence at the baseline were for Ascaris 33.2\% followed by hookworm with $24.1 \%$ and Trichuris with $6.5 \%$.

The relationship between sex and prevalence showed no significant association between host sex and the prevalence of Ascaris; however, the prevalence of hookworm $(\mathrm{p}=0.06)$ and Trichuris $(p=0.01)$ among females $(30.5 \%$ and $11.6 \%$ respectively) was significantly higher than among males (18.3\% and $1.9 \%$ ). No significant association between age and prevalence of the three intestinal helminths was found (Figure 1).

The coexistence of two arbitrary infections showed no correlation between Ascaris and Trichuris or Ascaris and hookworm. However, hookworm infection with Trichuris was found to have strong association ( $p=0.02)$.

The prevalence of the intestinal helminths after treatment is shown in Table 2. The prevalence of Ascaris and Trichuris was reduced by $12 \%$ and $61 \%$ respectively at the 9 -month interval but increased by $31 \%(p<0.01)$ and $80 \%$ at 18 months. Prevalence of hookworm increased further than baseline by $12 \%$ and $44 \%(p<0.01)$ at the 9 and 18-month follow-up.

No significant differences in the reinfection rates were found between the treated and negative cases.

Table 1 - Prevalence of single and multiple helminthic infections among schoolchildren in Low-Napo (October 1991).

\begin{tabular}{lrr}
\hline Helminthic infections & $\mathrm{N}^{\mathrm{r}}$ & $\%$ \\
\hline Negative & 103 & 51.8 \\
Ascaris & 42 & 21.1 \\
Hookworm & 22 & 11.1 \\
Trichuris & 3 & 1.5 \\
Ascaris + hookworm & 19 & 9.5 \\
Ascaris + Trichuris & 3 & 1.5 \\
Hookworm + Trichuris & 5 & 2.5 \\
Ascaris + hookworm + Trichuris & 2 & 1 \\
\hline Total & 199 & 100 \\
\hline
\end{tabular}

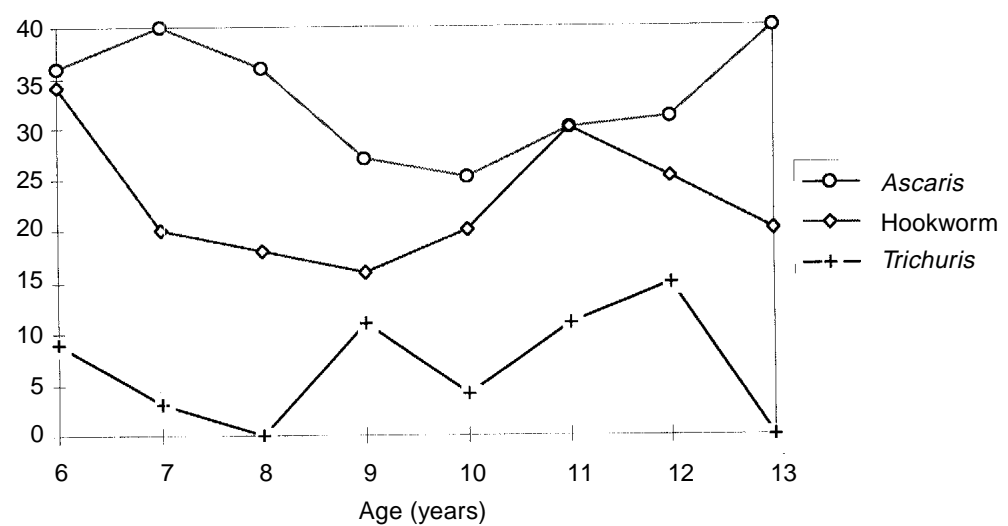

Figure 1 - Helminth infection rates according to age among schoolchildren in Napo province, Ecuador (October 1991). 
Table 2 - Intestinal helminth infection among schoolchildren before and after treatment (Napo, Ecuador).

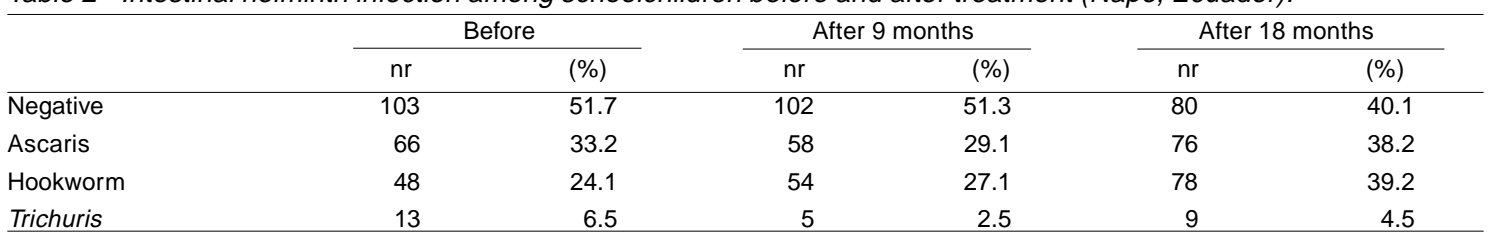

\section{DISCUSSION}

The high prevalence of intestinal nematodes among Naporuna schoolchildren could be related to behavioral factors such as poor hygienic practices, walking barefoot or lack of safe water supplies.

Studies in Nigeria ${ }^{4}$ found a higher prevalence of hookworm among males $(p<0.052)$. However, the present study found higher prevalence among females. No definitive explanation has been found to this finding; however, one suggestion might be that the use of shoes by males was observed to be greater than among the females thus affording less risk of skin-soil contact.

After 9 months of treatment, the lower prevalence of infection for Ascaris and Trichuris observed in this study is similar to findings in Kenya ${ }^{8}$. However, hookworm prevalence increased after 9 months. All three were close to or surpassed baseline levels (Table 2). The increased prevalence during follow-up could be related to higher transmission (especially hookworm), due on one hand to the increased time the children spend at home during the school-holidays (probable an important source of infection) and on the other hand, to the more favorable environmental conditions following the rainy season in July ${ }^{1}$.

In conclusion, our findings suggest that a single course of treatment with mebendazol had little impact on the control of helminth infection.

\section{ACKNOWLEDGEMENTS}

The authors would like to thank Dr. Azn.rez, who initiated the school program, without whose work and advice the study would have been impossible. Special thanks to Dr. Hurtig for her numerous corrections and valuable suggestions and to John Williams for the last revision of the draft. We are also grateful to Sandi Yura communities and participants for their cooperation in the study.

\section{REFERENCES}

1. Albonico M, Smith PG, Ercole E, Hall A, Chwaya HC, Alawi KS, Savioli S. Rate of infection with intestinal nematodes after treatment of children with mebendazole or albendazole in a highly endemic area. Transactions of the Royal Society of Tropical Medicine and Hygiene 89: 538-541, 1995.

2. Amunarriz M. Salud y enfermedad: Patología tropical en la región amazônica ecuatoriana. Cicame, Pompeya, Ecuador, 1984.

3. Asaolu SO, Holland CV, Crompton DWT. Community control of Ascaris lumbricoides in rural Oyo State, Nigeria: mass, targeted and selective treatment with levamisole. Parasitology 103: 291-298, 1991.

4. Asaolu SO, Holland CV, Jegede JO, Fraser NR, Stoddard RC, Crompton DWT. The prevalence and intensity of soiltransmitted helminthiases in rural communities in
Southern Nigeria. In: Annals of Tropical Medicine and Parasitology 86:279-287, 1992.

5. Connolly KJ, Kvalsig JD. Infection, nutrition and cognitive performance in children. Parasitology 107: S187-S200, 1993.

6. Davis A. Ascariasis: drugs and drug policy. In: Crompton DWT, Nesheim MC, Pawlowski ZS (eds) Ascariasis and its Public Health Significance, Taylor and Francis: London and Philadelphia, p. 239-244, 1985.

7. Ejezie GC. The parasite disease of school children in Lagos state, Nigeria. Acta Tropica 38:79-84, 1981.

8. Magnussen $P$, Muchiri E, Mungai P, Ndzivu M, Ouma J, Tosha S. A school-based approach to the control of schistosomiasis and intestinal helminth infections in children in Matuga, Kenya: impact of a two-year chemotherapy programme on prevalence and intensity infections. Tropical Medicine and International Health 9:825-831, 1997. 
Revista da Sociedade Brasileira de Medicina Tropical 33:69-73, jan-fev, 2000

9. San Sebastián M. Prevalencia de enfermedades entre los escolares indígenas de la provincia del Napo. In: Primer Congreso Amazônico de Medicina Tropical, Tena, Ecuador, 1995.
10. World Health Organization. Prevention and control of intestinal parasitic infections. WHO Technical Report. Serie 794. Geneva, 1987. 